entitled "Public Employee Unionism in Downstate Illinois Municipalities." His training in public administration notwithstanding, John discovered his true interests at Rochester-British and comparative politics, "the Behavioral Revolution" (words and emphasis his), group theory, and Arthur Bentley, probably in that order.

To further his interests in British politics and group theory, John did research in England on the British Legion during the 1954-55 academic year on a fellowship from the Fund for the Advancement of Education. (John had many stories to tell of his voyage aboard the Queen Mary) The fellowship led to publication in the Western Political Quarterly of "The Role of an Interest Group Leader in the House of Commons," the work for which John is best known. The article was reprinted in Heinz Eulau and John Wahlke's Legislative Behavior and was also cited in many bibliographies dealing with British politics or group theory.

John came to what was the University of Wichita in September 1957 and remained until his retirement in May 1984, save for the 1964-65 academic year when he filled in for John Kautsky, who was on leave from Washington University. Vice president of the Midwest Political Science Association during 1974-75, John was a professional political scientist in every sense, but he was also much more. He was a man who loved learning. He told the local Pi Sigma Alpha members at his retirement of his visit to the University of Virginia near the end of World War II. It was his first visit to a campus since the war began. So overjoyed to be at a center of learning once again, John expressed this joy by rolling down a hill.

As a man of learning, John endeavored to pass on his erudition to his students. At Wichita State John was director of the Honors Program from 1968 through the spring of 1971. Encouraging his students to pursue a broad liberal education, John admonished them not to concentrate all of their academic effort within the narrow confines of a major. One of John's students, Wes McCarty, religiously followed John's advice and sought to become a wellrounded student. When Wes died untimely of leukemia, his parents, remembering John's work with Wes, established an endowed departmental scholarship in honor of Wes which specified that the recipients were to pursue a broad liberal education. In reality the scholarship was as much a memorial to John Millett as to Wes McCarty. The creation of that scholarship led to the establishment of several other endowed scholarships for undergraduates. John was also known for his role as adviser to Pi Sigma Alpha. The induction of members was no casual matter for John. Instead, he arranged an annual induction banquet which he saw as an august and solemn rite.

John retired from Wichita State in May of 1984. The department planned a grand gala to honor him. Political scientists and former students from around the country were planning to attend John's retirement celebration. But John's doctor advised him that he needed immediate by-pass surgery if he were to live. So the departmental chair called invited guests around the country to tell them that the celebration has been cancelled. John's retirement party was rescheduled for May of 1985, but it was anti-climatic. For many years John believed that his doctors had conspired against him to deny him his retirement party.

Despite his disappointment over the cancelled retirement fete and his failing health in his last years, John had a good life in retirement. He and his wife Marie, whom he had married on June 1, 1975, moved to Sarasota in 1986. Active in Grapevine International Folk Dancers and other dance groups since the time of his marriage, John had a longtime dream come true when he and Marie took a folk dance tour of Greece during his retirement. Until just a few months before his death, John and Marie folk danced as often as four evenings a week.

Aside from folk dancing, John followed the stock market closely, just as his father, an Episcopal minister, had done. When his congregation cut the Rev. Mr. Millett's salary during the depression, the minister took to playing the stock market to make up the difference. The Rev. Mr. Millett made such handsome profits that a nicely sum of John's retirement income came from investments John inherited from his father. For years John touted the shares of Hesston Corp., a Kansas manufacturer of farm machinery. Hesston did not prosper, and John lost money. Yet he maintained his interest in the market and endured much goodnatured ribbing about the fate of Hesston.

A strong supporter of the Unitarian Universalist fellowship in Wichita-believe in one God at most," John would proclaim-John was an active Unitarian in Sarasota as well. But this erudite man with a liberal education also found time for other pursuits. He took piano lessons. A friend who visited him at the "Millett Hilton" recalls him "proudly playing Bach, Chopin, and Haydn pieces in recitals with students of all ages." He became an expert on the birds of Florida and attended the Sarasota Music Festival every June. He even found time to volunteer as a paraprofessional at a pre-school and to serve on its Board of Directors. Those wishing to honor the memory of John may make a contribution to that pre-school, Helen R. Payne Day Nursery, P.O. Box 3365, Sarasota, Fla. 34230, or to the Unitarian Universalist Church, 3975 Fruitville Road, Sarasota, FL 34232.

Kenneth N. Ciboski

David N. Farnsworth (emeritus)

Melvin A. Kahn

James W. McKenney

James F. Sheffield, Jr. John E. Stanga

Wichita State University

\section{Donald E. Stokes}

Donald E. Stokes died of acute leukemia on January 26, 1997, at the University of Pennsylvania Medical Center. He was 69. He was the Class of 1943 University Professor of Politics and Public Affairs at Princeton University, where he had been a member of the faculty for 23 years and Dean of the Woodrow Wilson School of Public and International Affairs from 1974 to 1992.

Born April 1, 1927, in Philadelphia, Stokes earned his bachelor's degree from Princeton in 1951 and his doc- 
torate in political science from Yale in 1958. He taught at the University of Michigan from 1958 to 1974, serving as chairman of the political science department in 1970-71 and as dean of the graduate school from 1971 to 1974. He also taught as an associate member at Nuffield College, Oxford, and as a visiting professor at the University of the West Indies and the Australian National University.

Stokes served as vice president of the American Political Science Association and was a recipient of the Association's Woodrow Wilson Foundation Award. He was a fellow of the American Academy of Arts and Sciences, the National Academy of Public Administration, and the American Association for the Advancement of Science, and a former Guggenheim fellow.

Stokes is survived by his wife, Sybil; two daughters, Elizabeth Stokes and Susan Stokes; a sister, Eleanor Stokes Szanton; and three grandchildren. Both Sybil and Susan are political scientists and members of the American Political Science Association. What follows are two appreciations by colleagues who worked with and admired Don Stokes over his long and storied career.

\section{Donald Stokes and the Study of Electoral Politics}

For me, there will always be two distinct sides to Don Stokes. One is the courtly, magisterial "Dean Don" who led Princeton's Woodrow Wilson School for eighteen years, who was instrumental in bringing me to Princeton in 1991, and whose "decanal style verged on the regal" (as Anthony King aptly put it) even after he stepped down from the deanship in 1992.

The other Don Stokes is one I never really knew personally, though I held him in equally high regard. $\mathrm{He}$ is the "early Stokes" who, in a mere dozen years following his arrival at the University of Michigan in 1958, coauthored three classic books that laid the groundwork for everything that has followed in the scholarly study of electoral politics. Having reached the pinnacle of his scholarly field within that brief period, Stokes by 1970 was turning his attention to academic administration and institution-building, first at Michigan and then at Princeton.

Stokes's scholarly career began with a bang when, only two years after arriving in Michigan, he appeared as coauthor with his Survey Research Center colleagues, Angus Campbell, Philip Converse, and Warren Miller, of The American Voter. This book the single most important publication in the entire history of voting research, and the primary source of the ideas, problems, and data that have propelled most of the subsequent development of the field. The American Voter portrayed an electorate whose orientations toward politics were strongly shaped by party loyalties developed early in life, whose familiarity with and attachment to abstract ideologies and policy agendas was remarkably limited, and whose votes in specific elections reflected the overlaying of short-term forcesmost notably, in the 1950 s, the personal popularity of Dwight Eisenhower-on top of more persistent partisan alignments reflecting the social cleavages of the New Deal or even of the Civil War era.

Every major element of this portrait of the American voter has been subjected in the subsequent 37 years to energetic criticism and painstaking reevaluation using new data, theories, and research methods. By the standards of empirical social science, The American Voter has proven to be a work of unsurpassed influence and staying power.

It is difficult to disentangle Stokes's specific contributions to the remarkable collaborative effort that produced The American Voter. However, his distinctive interests and skills emerged more clearly in his subsequent publications, several of which were reprinted among the essays by the same team collected in Elections and the Political Order. If The American Voter was a scholarly symphony, Elections and the Political Order was chamber music of the finest sort, with a stimulating mixture of solo turns and duets within the flexible framework of the larger ensemble. Stokes's contributions to the mix fell into three categories: his brief but important essay on "Spatial Models of Party Competition," his classic articles with Warren Miller on congressional representation, and two pieces of the several he would eventually produce using aggregatelevel data and simple mathematical models to explore the broad historical dynamics of electoral systems.

"Spatial Models of Party Competition" seems to have been one of Stokes's own favorite works; indeed, it is the only one of his writings on electoral politics that he returned to long after it was originally written (in chapters for Dennis Kavanagh's 1992 volume on Electoral Politics and, with his colleague John Dilulio, for Michael Nelson's 1993 volume on The 1992 Elections). The essay is, in the first instance, a penetrating appreciation and critique of Anthony Downs's An Economic Theory of Democracy, tracing the antecedents of Downs's theory in the work of Hotelling and Smithies, noting in passing the similarity between Downs's framework and the framework developed by Duncan MacRae for analyzing roll call votes (a similarity exploited in much subsequent work by Poole and Rosenthal and others), and emphasizing the real limitations of Downs's axioms of unidimensionality, fixed structure, and common reference. Stokes's comments on "the interchange between theory-building and empirical observation" gracefully staked out a sensible middle ground in what has since come to be thought of as a conflict between formal theories of politics on one hand and empirical studies of political behavior on the other.

However, the most enduring positive contribution of "Spatial Models of Party Competition"-and the point Stokes himself was drawn to revisit-was the distinction between "position issues" of the sort encompassed by Downs's theory and the "valence issues" that actually seemed to "have held the center of the stage" in American political history, from the economic panics of the 19 th century to the issues of Korea, communism, and corruption in 1952. Such "valence issues," in Stokes's parlance, "involve the linking of the parties with some condition that is positively or negatively valued by the electorate" as a whole, rather than the positioning of the parties on a dimension along which voters' own 